NBER WORKING PAPER SERIES

STRATEGIC USE OF ANTIDUMPING LAW TO ENFORCE

TACIT INTERNATIONAL COLLUSION

Robert W. Stalger

Frank A. Wolak

Worklng Paper No. 3016

NATIONAL BUREAU OF ECONOMIC RESEARCH

1050 Massachusetts Avenue

Cambridge, KA 02138

June 1989

We thank Kyle Bagwel1, Joe Farre11, and Tom Prusa for helpful comments. This paper was written whlle stalger was a National Fellow of the Hoover Institution. This paper is part of NBER's research program in International studies. Any opinions expressed are those of the authors not those of the National Bureau of Economic Research. 
NBER Working Paper \#3016

June 1989

\title{
STRATEGIC USE OF ANTIDUMPING LAW TO ENFORCE \\ TACIT INTERNATIONAL COLLUSION
}

\begin{abstract}
ABSTRAGT
We consider the impact of domestic antidumping law in a two-country partial equilibrium model where domestic and forelgn firms tacitly collude in the domestic market. Firms engage in an infinitely repeated game, with each period composed of a two-stage game. In the first stage each firm chooses capacity before stochastic domestic demand is realized. In the second stage, after demand is realized, each firw then sets price. We show that the introduction of domestlc antidumping law typlcally leads to the filing of antidumping sults by the domestlc industry in low demand states. and to more successful collusion and grester market share for domestic firms during perlods of low demand as a result. This occurs in spite of the fact that antidumping duties are never actually imposed. That 1 , the entire effect of antidumping law comes in the form of threat to punish foreign firms with a duty if they should "misbehave." Such a threat is made credible by filing a sult and, because it is credible, never has to be implemented. We conclude that the trade-restricting effects of antidumping law may have little to do with whether dutles are actually imposed.
\end{abstract}

Robert $W$. Stalger Stanford University Stanford, CA 94305
Frank A. Wolak

Stanford Untversity

Stanford, CA 94305 


\section{Introduction}

The belief that dumping on foreign markets is closely ilnked to cartelization is nearly as old as the lssue of dumping in International trade Itself. This view played a critical role in the evolution of antidumping laws in the early 20 th century. Viner (1966, p.242) notes, for Instance, that the first antidumping legislation adopted in the U.S., as contained in Sections 800-801 of the Revenue Act of 1916, came largely in response to the alleged dumping threat from the highly cartelized and heavily protected German Industries. Th1s alleged dumping activity took the form of unloading excess Industrial capacity from the German cartels on to the noncartelized (and segmented) U.S. market. Inspired by this fear, the original Intent of the law was to provide protection for U.S. firms against "unfair competition" resulting from the dumping activity of cartelized firms abroad.

While the importance of cartels in the evolution of antidumplng law is widely acknowledged, the impact of such laws on the performance of cartels 1s less well understood. ${ }^{1}$ Yet, antidumping law 1 s $11 k e l y$ to alter the environment within whIch cartels operate in Important ways. For example. in the particular dumping context discussed above, the introduction of antiduming law Into the domestic country will effect the freedom with which cartelized forelgn firms can dump excess capacity on the noncartelized domestic market. This, in turn, may have an Important Impact on the degree of collusion sustainsble by the forelgn cartel. Moreover, when made avallable to cartel members, antidumping law may become a tool to enforce

1 Recent work by Dixit (1988), Ethier (1988), and Prusa (1988) analyze the effects of antidumping law on firm Interaction in a static setting. 
collusion. The Second International steel Cartel of the 1930s, for example. exploited the existence of antiduming law to police the dumping activities of its own members in cartelized markets. In at least one instance. antidumping action was used successfully by one member of the International Steel Cartel against another to enforce the cartel's price arrangements. ${ }^{2}$ The impact of antidumping laws on collusive behavior thus seems to be a potentially fruitful area of research, and one that we begin to explore in this paper. We do so in the context of an environment where firms collude tacitly and are limited to self-enforcing arrangements. The general setting we choose is one of an infinitely repeated game in which firms face stochastic market demand and must choose each period's capacity before the market demand for the period is realized. Once market demand for the period has been observed, and with their capacities for the period now fixed, firms then simultaneously choose prices. Within this setting, firms attempt to enforce collusion over capacity and price with the credible (subgame perfect) threat to forever revert to the static Nash equilibrium in the event of a defection from the cooperative arrangement. ${ }^{3}$ The most collusive

2 In January 1938, the South African Iron and Steel Corporation filed an antidumping petition against steel producers in the U.S. For selling steel in the South African market at prices below those agreed upon by the International Steel Cartel. Dumping duties were levied and the Cartel's pricing arrangements restored (see Hexner, 1943).

3 Our model can be viewed essentially as either an infinitely repeated version of Kreps and Scheinkman (1983) wtth firms facing stochastic market demand that is realized only after capacity is set for the period, or as a variation on Rotemberg and Saloner (1986a) with the introduction of a capacity-setting stage at the start of each period. Related work on pricesetting supergames with capacity constraints but without stochastic demand can be found in Brock and Scheinkmen (1985), Benoit and Krishna (1987), and Davidson and Deneckere (1987), among others. See also Rotemberg and Saloner (1986b) for an analysis of the impact of import quotas on collusive behavior. 
equilibrium will typically have flrms carrying excess capacity in low demand states, and it is with respect to this excess capacity that antidumping lax has its effects.

The observations on antidumping law made at the outset suggest that, in the presence of tacit collusive behavior, the introduction of antidumping law may have very different effects depending on the competitive characteristics of the industry to which the law is made available. In Staiger and Wolak (1989), we consider the case in which the domestic industry is competitive but faces imports from firms behaving collusively in a segmented market abroad. In that paper, we show that the Introduction of domestic antidumping law is likely to lead to the filing of antidumping suits and the imposition of antidumping duties In low demand states, to less price collusion abroad, and to a lesser quantity dumped on the domestic market as a result.

In the present paper, we consider the impact of the introduction of antidumping law into the domestic country when domestic and foreign firms are tacitly colluding in the domestic market. Here we show that the introduction of antiduming law into the domestic country typically leads to the filing of antidumping suits by the domestic industry in low demand states, and to more successful collusion and greater market share for domestic firms during periods of low demand as a result. This occurs in spite of the fact that antiduming duties are never actually imposed. That is, in this setting, and as distinct from the use of antidumping law by competitive industries analyzed in Staiger and wolak (1989), the entire effect of antidumping law comes in the form of a threat to punish foreign firms with duty if they should "misbehave". Such a threat is made 
credible by flling the suit and, because it is credible, never has to be implemented." The results then follow from the fact that by filing an antidumping suit, the domestic Industry is able to diminish the incentives of forefgn firms to aggressively pursue domestic market share, i.e., defect from the collusive price arrangement. Hence, with defection now relatively less attractive for forelgn firms, higher collusive prices in periods of low demand can be sustained with the flling of an antidumping suit, but only after appeasing the domestic industry's incentive to defect by giving domestic firms a larger share of the low-demand market. These results are developed formally below.

The remainder of the paper proceeds as follows. In section II we develop the model in the absence of antidumping law. Section III introduces antidumping law into the domestic country and explores the consequences for collusive behavior. Finally, section IV concludes with a summary of our results.

\section{The Mode1}

We consider an infinitely repeated model of two firms, home (no *) and forelgn (*), seliling to the home market where demand is stochastic and fluctuates between high and low states. At the beginning of any period, firms first must simultaneously set capacity $K$ and $K *$, facing per unit capacity costs $r>0$. Once capacity cholces for the perlod are made, the state of demand for the perlod is revealed. We assume for simplicity that demand takes the Iinear form

- This prediction is consistent with the large number of antidumping sults that are flled and then later withdrawn (see Prusa, 1988, and section III below). 
(1) $D_{1}=\alpha_{1} \cdot \beta P \quad 1-\{\mathrm{L}, \mathrm{H}\}, \alpha_{\mathrm{H}}>\alpha_{\mathrm{L}}>0, \beta>0$

with price as a function of home and foreign supplies $q$ and $q^{*}$, respectively, then given by

$$
P_{i}\left(q^{*} q^{*}\right)=\frac{\alpha_{i} \cdot\left(q+q^{*}\right)}{\beta}
$$

We assume that high demand occurs in any period with probability $\rho$. After observing the demand realization for the period, the two firms then simultaneously set prices facing zero marginal costs of production (up to capacity).

\section{The Static Nash Equilibrlum}

We first characterize the unique static Nash equilibrium to this game which will serve as the credible (subgame perfect) punishment in the repeated game to be studied next. We rely heavily on Kreps and Scheinkman (1983) and therefore on the particular (efficient) rationing rule underlying their results. Specifically, conswmers buy first from the cheapest supplier, and income effects from price changes are absent."

- Provided that (1n a sense to be formalized) the differential between high demand and low demand is sufficiently great, there exists a unique Nash equilibrium to the static game characterized by symetric capacity choices

5 See Davidson and Deneckere (1986) for results from a static twostage game under different rationing rules. 
(2) $\mathrm{K}^{\mathrm{k}}-\frac{\rho \alpha_{\mathrm{B}} \cdot \beta \mathrm{r}}{3 \rho}$

and prices in the high and low demand states of

(3) $\mathrm{P}_{\mathrm{B}}^{\mathrm{K}}-\mathrm{P}_{\mathrm{B}}\left(\mathrm{K}^{\mathrm{Y}}+\mathrm{K}^{\mathrm{H}}\right)=\frac{\alpha_{\mathrm{H}}-2 \mathrm{~K}^{\mathrm{B}}}{\beta}$

and

(4) $P_{L}^{k}=0$.

Thus, capacity choices are such that in high demand states, the two firms sell their capacity at the market clearing price, while in low demand states, price is set to marginal cost (which equals zero) and there is excess capacity.

To show that this is indeed the unique Nash equilibrium to the static game (under the condition of suffictently large differences between high and low demand states), we follow Kreps and Scheinkman (1983) and first define $q_{1}(q) \quad i-L, H$ as the Cournot duopoly best response functions for firms facing the linear demand function given in (1) and zero marginal costs. It is straightforward to check that these best response functions must satisfy the following sets of inequalities:

(5) $q_{L}(q \geq 0)<D_{L}(0)$ 
and

(6) $q_{B}\left(q \geq D_{L}(0)\right) \leq q_{H}\left(D_{L}(0)\right)<q_{B}(0)<D_{B}(0)$

where the notation $q_{1}(q \geq x)$ denotes the value of $q_{1}(q)$ for all values of $q \geq x$. Moreover, the symmetric Cournot-Nash equilibrium output choice facing high demand (and zero marginal costs), $q_{H !}^{N}$, is given by

(7) $q_{H}^{N}-\frac{\alpha_{B}}{3}$.

Thus, using (2) and (7), and provided $\rho$ is strictly positive.

$$
\mathrm{K}^{\mathrm{N}}<\mathrm{q}_{\mathrm{g}}^{\mathrm{II}} \text {. }
$$

It thus follows that

(8) $K^{H}<q_{H}\left(K^{H}\right) ; K^{H}<q_{B}\left(q \leq q_{B}\left(K^{H}\right)\right)$.

Finally, we assume that the differential between high demand and low demand is sufficiently great in the sense that

(9) $\alpha_{B} \cdot 4 \alpha_{L} \geq \frac{\beta I}{\rho}$ 
which, using (1) and (2), implies ${ }^{6}$

(10) $K^{N} \geq D_{L}(0)$.

Putting (5), (6), (8), and (10) together yields

(11) $\left\{\begin{array}{l}q_{L}(q>0)<D_{L}(0) \leq K^{N}<q_{H}\left(K^{N}\right) \leq q_{H}\left(D_{L}(0)\right)<q_{H}(0)<D_{H}(0) \\ K^{N}<q_{H}\left(q \leq q_{H}\left(K^{N}\right)\right)\end{array}\right.$

With (11) we are now ready to characterize a firm's expected profits in the static game as a function of its capacity choice facing a capacity choice $K^{N}$ from its rival. Consider first the range of firm capacity responses to $K^{\mathbb{N}}$ satisfying

(12) $D_{\mathrm{L}}(0) \leq K \leq \mathrm{q}_{\mathrm{B}}\left(\mathrm{K}^{\mathrm{N}}\right)$.

Suppose that the high demand state is realized. Then for all capacity choices satisfying (12), it must be true that

(13) $K \leq q_{B}\left(K^{H}\right) ; K^{N}<q_{B}(K)$.

The first inequality is a direct consequence of (12) and the second inequality follows from (11). Appealing to Proposition $I(a)$ of Kreps and Scheinkuan (1983), we then have that capacity responses satisfying (12)

B Condition (9) is in fact more than enough to yield (10), but will be needed for uniqueness. 
yield high-demand revenues for the firm of $P_{B}\left(K+K^{N}\right) \cdot k$ : each firm sells its entire capacity at the market clearing price. Alternatively, if realized demand is low, then by (11) and (12)

(14) $K \geq D_{L}(0) ; K^{*} \geq D_{L}(0)$.

Under (14), either firm can satisfy the entire market in the law demand state for any nonnegative price. Hence, capacity constraints do not upset the standard Bertrand equilibrium in which price equals marginal cost (which is zero), so that low demand revenues for the firm are zero. With this information we can now write the firm's expected profits facing $K^{k}$ for $K$ in the range defined by (12) as

(15) $E \pi\left(K, K^{H}\right)-\rho P_{g}\left(K+K^{H}\right) \cdot K-r K$ for $K \in\left[D_{L}(0), q_{B}\left(K^{H}\right)\right]$.

Next consider the range of firm capacity responses to $K^{*}$ corresponding to

(16) $x \geq q_{H}\left(k^{H}\right)$.

Clearly (14) will still hold over this range, so that low demand states continue to yield zero revenues for the firm. Suppose, then, that demand is high. Together, (11) and (16) imply

$$
K>K^{N} ; K \geq q_{B}\left(K^{n}\right) ; K^{N}<D_{B}(0)
$$


Appealing to Proposition I(b) of Kreps and Scheinkman (1983), we then have that the firm's revenues with high demand will be its "Stackelberg follower" revenues $P_{H}\left(q_{B}\left(K^{N}\right)+K^{*}\right) \cdot q_{B}\left(K^{H}\right)$ when (16) holds. Thus, expected profits for capacity responses to $K^{N}$ in the range given by (16) are

(17) $\operatorname{EH}\left(K, K^{H}\right)=\rho P_{B}\left(q_{B}\left(K^{H}\right)+K^{H}\right) \cdot q_{y}\left(K^{H}\right)-$ rK for, $K \geq q_{H}\left(K^{H}\right)$

with (17) equal to (15) when $K=q_{g}\left(K^{N}\right)$. W1th $r>0$, the expression in (17) 15 maximized over $K$ in the range given by (16) when $K=q_{y}\left(K^{N}\right)$. Therefore, 1t will never pay the firm to respond to $K^{N}$ with a $K$ that violates. the right-hand Inequality of (12).

Finally, consider the range of firm capacity responses to $\mathrm{K}^{\mathrm{N}}$ corresponding to

(18) $\mathrm{K} \leq \mathrm{D}_{\mathrm{L}}(0)$

Together, (11) and (18) Imply that (13) continues to hold, so that firm revenues with $h 1$ gh demand will be $P_{B}\left(K+K^{N}\right) \cdot K$. Suppose, then, that demand 1s low. Together, (11) and (18) imply

(19) $K^{\prime \prime} \geq K ; K^{\prime \prime}>q_{L}(K) ; K \leq D_{L}(0)$.

Appealing once nore to Proposition I(b) of Kreps and Scheinkman (1983). we then have that the firm's revenues with low demand will be no greater than 1 ts rival's "Stackelberg follower" revenues $P_{L}\left(K+q_{L}(K)\right) \cdot q_{L}(K)$ when $(18)$ holds. Thus, expected profits for capacity responses to $x^{H}$ in the range 
given by (18) are no greater than

(20) $\overline{E \Pi}\left(K, K^{\#}\right)-\rho P_{B}\left(K+K^{*}\right) \cdot K+(1-\rho) P_{L}\left(K+q_{L}(K)\right) \cdot q_{L}(K)-$ rK for $K \in\left[0, D_{L}(0)\right]$

with (20) equal to (15) when $K=D_{L}(0)$. However, it can be shown that, given our assumption $(9), \overline{E \Pi}\left(K, K^{k}\right)$ takes 1 ts maximum value for $K$ in the range given by $(18)$ at $K=D_{L}(0)$. Thus we have

$$
E \Pi\left(K \in\left[0, D_{L}(0)\right], K^{N}\right) \leq \overline{E \Pi}\left(K \in\left[0, D_{L}(0)\right\}, K^{W}\right) \leq \overline{E \Pi}\left(K-D_{L}(0), K^{N}\right)-E \Pi\left(K-D_{L}(0), K^{N}\right) .
$$

Essentially, assumption ( 9 ) assures that high demand states are of sufficlent importance to the expected profits of the firm that it would never find profitable a reduction of capacity for the purpose of generating higher Nash profits in low demand states. Hence, under assumption (9) it w11l never pay the firm to respond to $K^{*}$ with a $K$ that violates the left-hand inequality of (12).

We are thus left with (15) as the portion of the firm's expected profit function relevant to finding the best response to $k^{*}$. To find this best response to $K^{m}$, the first order conditions of (15) can be solved to yield (2), with (3) and (4) then following from the preceding discussion. This establishes that (2), (3) and (4) characterize a Nash equilibrium to the static game provided that the difference between $\mathrm{high}$ and low demand is sufficiently great (in the sense of (9)). Uniqueness then follows directly by using the preceding arguments to rule out the existence of additional equilibria characterized by min $\left(K, K^{*}\right) \geq D_{L}(0)$, and by using $(9)$ and a slight variation on the preceding arguments to rule out the existence of 
equilibria characterized by $\min \left(K, K^{*}\right)<D_{L}(0) .^{\prime}$

\section{The Monopoly Solution}

Before turning to the dynamic game, we consider the monopoly solution to the static game above. This will provide the collusive ideal toward which the two firms will strive in the repeated setting of the next subsection.

The monopolist's problem is much simpler than the duopoly examined above since it does not involve a price setting game subject to capacity constraints. The problem is simply to choose capacity facing uncertain demand, and then upon the realization of demand for the period to choose the profit maximizing quantity to sell subject to the constraint that quantity delivered be no greater than capacity.

Consider first the choice of output given a low demand realization. Low demand profits (revenues) as a function of output $q$ are given by

(21) $\Pi_{L}^{H}(q)-P_{L}(q) \cdot q$.

The monopolist's unconstrained profit maximizing quantity choice if the demand realization is low is, from the first-order condition of (21), given by $q-\alpha_{L} / 2$. Because the monopolist can sell at most its capacity $K$. the constrained quantity choice is characterized by

7 The veriation involves replacing $K^{N}$ with $K^{H}$ (defined by (24)) in equation (20) and noting that, with $K(K)$ denoting capacity best-response functions, $K\left(K^{B}\right) \leq K\left(K e\left[0, K^{B}\right]\right) \leq K^{H}$. The proof then establishes under condition (9) that $K\left(K^{*}\right) \in\left[D_{L}(0), K^{*}\right]$ which, together with the inequalities above, Implies that any capacity choice $K e\left[0, K^{H}\right]$ by one's rival will induce a best capacity response $K\left(K \in\left[0, K^{k}\right]\right) \in\left[D_{L}(0), K^{t /}\right]$. Hence, no equilibria can exist with $\min \left(K, K^{*}\right)<D_{L}(0)$. 


$$
\hat{q}_{L}(K)-\min \left(K, a_{L} / 2\right) \text {. }
$$

Thus, expected monopoly profits as a function of capacity choice $K$ are given by

(22) $E \Pi^{M}(K)=\rho P_{B}(K) \cdot K+(1-p) \Pi_{L}^{M}\left(\hat{q}_{L}(K)\right)-r K$,

which is strictly concave in $K$.

Assuming $K>\alpha_{\mathrm{L}} / 2$, so that capacity does not bind in low demand states, the first order condition for maximizing (22) is

(23) $\frac{\partial \sin ^{\mathrm{M}}(K)}{\partial K}=0-\rho\left(\frac{\alpha_{H}-2 K}{\rho}\right)+(1-\rho) \frac{\partial \Pi_{L}^{M}}{\partial q} \frac{\partial \hat{q}_{L}(K)}{\partial K}-r$.

However, for $K>\alpha_{L} / 2$, we have $\frac{\partial \hat{q}_{L}(K)}{\partial K}=0$, so that (23) yields the monopoly capacity choice

(24) $\mathrm{K}^{\mathrm{t}}-\frac{\rho \alpha_{\mathrm{y}}-\beta \mathrm{r}}{2 \rho}$,

and monopoly prices

(25) $P_{B}^{H}-P_{B}\left(K^{H}\right)$ 
and

(26) $P_{L}^{M}-\frac{\alpha_{L}}{2 \beta}$.

Note that (2) and (24) imply $K^{M}-(3 / 2) K^{N}$. Finally, assumption (9) ensures that $K^{M}>a_{2} / 2$ as assumed in the derivation of (24). Thus. the monopoly solution has $K^{M}$ chosen such that in high demand states all capacity is utilized, whlle in low demand states there exists excess capacity.

\section{The Dynamic Game}

We are now ready to characterize the dynamic game. We explore an infinitely repeated version of the static game described above. The two firms achieve the most collusive (symmetric) outcome sustainable by the credible (subgame perfect) threat to revert forever to the static Nash equilibrium characterized above in the event that either firm defects. In order to focus on the dynamics of sustaining collusion in a stochastic environment, we will maintain assumptions which allow the firms to sustain their most preferred capacity choice. Thus, any difficulties in sustaining full collusion will occur with regard to the pricing decisions, which by assumption, are made once demand for the period has been observed. We begin by deriving the conditions under which the fully collusive capacity and price choices are sustainable by the threat of Nash reversion. 
The Fully Collusive Eautlibrium

In the fully collusive equilibrium, firms make symmetric capacity cholces $K^{C}$ and pricing decisions $P_{i}^{C}$ to repllcate the monopoly outcome of the previous subsection, so that

(27) $\overline{k^{c}}-\frac{k^{k}}{2}=\overline{k^{c}}$

(28) $\tilde{P}_{\mathrm{B}}^{\mathrm{C}}-\mathrm{P}_{\mathrm{g}}^{\mathrm{M}}-\tilde{\mathrm{P}}_{\mathrm{B}}^{\mathrm{C}}$

(29) $\bar{P}_{L}^{C}=P_{t}^{H}=\bar{P}_{i}^{c *}$,

where "ns denote fully collusive magnitudes. If full collusion is sustalnable, then nelther firm can have an incentive to unilaterally defect from the cooperative cholces characterized by (27), (28), and (29). Because both firms are completely symetric, we characterize the "no defection" condition in the domestic firm notation. A firm may defect from the cooperative agreement elther in 1 ts capacity cholce or in fts price choice. The former defection can not be condltioned on the state of demand (which is unknown at the time), wh1le the latter defection can be conditioned on the dewand realization for the perlod. We consider each in turn.

If the domestic flrm unilaterally defects from 1ts cooperative capacity cholce $\bar{K}^{c}$, 1t w1ll face noncooperative pricing in the second stage of the current period, followed by infinite repetition of the noncooperative Nash equilibrium characterized earlier. Denoting the defection capacity as $K^{D}$, assumption (9) rules out defection capacity cholces $K^{D}<D_{L}(0)$ in 
response to a foreign capacity choice of $\bar{k}^{c}$ in the same way that this assumption ruled out capacity choices $K<D_{L}(0)$ in response to a forelgn capacity choice of $K^{N}$ in the static game analyzed earlier. Suppose, then. that

(30) $K^{D} \geq D_{L}^{\prime \prime}(0)$.

Since $\overline{K^{c}} \geq D_{L}(0)$ is assured by (9), defection capacity choices satisfying (30) allow either firm to satisfy the entire market in low demand states for any nonnegative price. Hence, for $K^{D}$ in the range given by $(30)$, the standard Bertrand equilibrium obtains in low demand states with price equal to marginal cost and low demand revenues of zero for the defecting firm. On the other hand, defection capacity choices $K^{D}>q_{H}\left(K^{c}\right)$ in response to a foreign capacity choice of $\bar{K}^{c}$ can be ruled out as long as $r>0$ in an exactly analogous way that capacity choices $K>q_{H}\left(K^{N}\right)$ in response to a foreign capacity choice of $\mathrm{K}^{\mathrm{N}}$ were ruled out in the static game. Hence we also have

$$
K^{D} \leq q_{B}\left(K^{C}\right) ; \bar{K}^{C}<q_{B}\left(q_{H}\left(\kappa^{C}\right)\right) \leq q_{H}\left(K^{D}\right)
$$

which (appealing once nore to Proposition $I(a)$ of Kreps and Scheinkman (1983)) assures that $\bar{K} c$ and $K^{j}$ are such that in high demand states the two firms will sell all of their capacity at the market clearing price. Thus, a firm's current expected gain from defecting to $K^{D}$ in the relevant range is given by 
(31) $\Omega\left(K^{D}, \bar{K}^{c}, \bar{P}_{L}^{c}\right)-\rho\left[P_{B}\left(K^{D}+\bar{K}^{c}\right) \cdot K^{D} \cdot P_{H}\left(K^{c}+\bar{K}^{c}\right) \cdot \bar{K}^{c}\right\}$

$$
+(1-\rho)\left(0-\bar{P}_{L}^{C} \frac{D_{L}\left(\tilde{P}_{L}^{C}\right)}{2}\right)-r\left[K^{D}-\bar{K}^{C}\right]
$$

where the first term in brackets is the revenue from defecting in the high demand state less the collusive revenue in that state, the second term in brackets is the revenue from defecting in the low demand state (zero) less the collusive revenue in that state, and the last term captures the change in capacity costs associated with defection. The firm will choose $\mathrm{K}^{\mathrm{D}}$ to naximize (31). Direct calculation yields $K^{D}\left(\bar{K}^{C}, \bar{P}_{L}^{C}\right)-(3 / 2) \bar{K}^{c}-(3 / 4) K^{M}$, so that defection entails installing greater capacity than that permitted by the collusive arrangement. Substituting back into (31), we then have

(32) $\Omega\left(\bar{K}^{c}, \overline{\mathrm{P}_{L}^{\mathrm{C}}}\right)=\frac{\left(\bar{K}^{\mathrm{c}}\right)^{2}}{4 \beta} \cdot(1-\rho) \frac{\beta}{2}\left(\overline{\left.\mathrm{P}_{\mathrm{L}}^{\mathrm{C}}\right)^{2}}\right.$.

Now consider a defection from the cooperative price, with the defection price denoted by $\mathrm{P}_{1}^{\mathrm{D}}$ i-L,H. In the high demand state, defection must entail ralsing one's price above $\vec{p}_{B}^{C}$, since each firm sells its entire capacity at $\tilde{p}_{B}^{c}$. In the low demand state, defection entails shaving one's price just below $\bar{p}_{L}^{c}$. Using (9),

$$
K^{C}-k^{M} / 2-3 K^{M} / 4 \geq D_{L}(0) \geq D_{L}\left(P_{L}^{C} \geq 0\right) \text {, }
$$

so that a firm that defects by shaving its price below $P_{L}^{C}$ will have sufflclent capacity to capture the entire market. With this, the firm's , 
current gain to defecting from $\bar{p}_{i}$ will then be given by

$$
Q\left(P_{1}^{D}, \bar{P}_{1}^{C}\right)- \begin{cases}P_{B}^{D} \cdot \min \left\{\bar{K}^{c}, \max \left[0, D_{B}\left(P_{B}^{D}\right)-\bar{K}^{C}\right]\right) & \text { if } 1=\mathrm{H} \\ \frac{\bar{P}_{L}^{C} D_{L}\left(\bar{P}_{L}^{C}\right)}{2} & \text { if } 1=L\end{cases}
$$

where $\mathrm{Q}\left(\mathrm{P}_{\mathrm{B}}^{\mathrm{D}}, \overline{\mathrm{P}_{\mathrm{B}}^{\mathrm{C}}}\right)$ has the defecting firm facing a nonnegative residual demand and making sales equal to the minimum of this and Its capacity. The optimal defection price $P_{1}^{D}$ will be chosen to maximize (33). As discussed above, In the low-demand state, optimal defection entails shaving one's price just below $\bar{P}_{L}^{c}$ so that $P_{L}^{p}\left(\bar{P}_{L}^{c}\right)-\bar{P}_{L}^{c}$. For the high-demand state, direct calculations yield $\mathrm{P}_{\mathrm{B}}^{\mathrm{D}}\left(\mathrm{P}_{\mathrm{B}}^{\mathrm{C}}\right)-\overline{\mathrm{P}}_{\mathrm{H}}^{\mathrm{C}}$. Substitution Into (33) yields

(34) $\mathrm{D}\left(\mathrm{P}_{\mathrm{Z}}^{\mathrm{D}}\left(\overline{\mathrm{P}}_{\mathrm{g}}^{\mathrm{C}}\right), \overline{\mathrm{P}}_{\mathrm{B}}^{\mathrm{C}}\right)-0$

and

(35) $\mathrm{Q}\left(\mathrm{P}_{\mathrm{L}}^{\mathrm{D}}\left(\overline{\mathrm{P}_{\mathrm{L}}}\right), \overline{\mathrm{P}}_{\mathrm{L}}^{\mathrm{C}}\right)-\frac{\beta}{2}-\left(\overline{\mathrm{P}}^{\mathrm{C}}\right)^{2}$.

Thus, the firm's current Incentive to defect from the cooperative price is only positive in low demand states. In high demand states the firm already sells Its capacity with marginal revenue grester than (short run) marginal cost.

Defining $\omega\left(\bar{K}^{c}, \bar{P}_{L}^{C}, \bar{P}_{k}^{C}\right)$ as the present discounted value of maintalning perfect capacity and price cooperation Into the infinite future, which is 
itself a function of the perfectly cooperative capacity and price functions, the "no defection" condition that must hold if perfect cooperation in capacity and price is sustainable is given by

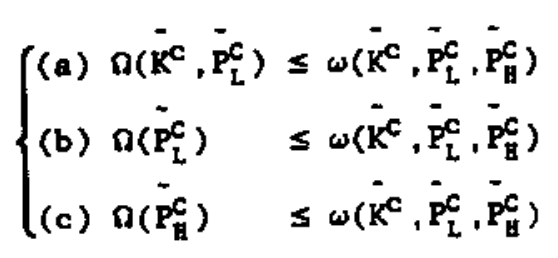

\section{The Most Collusive Equilibrium}

If (36) holds, then perfect collusion in capacity and price can be sustained and (27), (28), and (29) charecterize the equilibrium capacity and pricing policies of the two firms. However, if (36) does not hold, then perfect collusion in capacity and price cannot be sustainad. In this case we focus on the most collusive agreement sustainable by the threat of Nash reversion. Such an agreement will have at least one of the incentive constraints in (36) holding with equality, 1.e., binding. While (36 (c)) will clearly not bind in equilibrium as long as cooperation means anything $\left(\omega\left(K^{C}, P_{L}^{C}, P_{q}^{C}\right)>0\right)$, equilibrium could have either $(36(a))$ or $(36$ (b)) bind: the former corresponds to the case where perfectly collusive capacity choices are unsustainable, while the latter corresponds to the case in which perfectly collusive prices are unsustainable in low demand states. We will focus on the latter case, and provide parameter ranges which yield this case as an equilibrium.

Given that we have restricted our attention to cases in which perfectly collusive capacity choices are sustainable, the next question is what cooperative capacity level represents the most collusive choice. As noted 
above, if the threat of static Nash reversion is sufficient to sustain perfect price collusion given any cooperative capacity choice, then the firms will attempt to sustain the (symmetric) cooperative capacity choices $\mathrm{K}^{\mathrm{N}} / 2$ and support the fully collusive, $1 . e .$, monopoly, outcome. If, on the other hand, given capacity choices $k^{\mathrm{N}} / 2$ the firms find fully collusive pricing unsustainable by the threat of static Nesh reversion, it must be in the low demand state that full collusion is unsustainable since, by (34) and (35), only in this state is the current gain from price defection strictly positive. In the event that low demand states are associated with less than fully collusive pricing given capacity $\mathrm{K}^{\mathrm{M}} / 2$, it is possible that a choice of cooperative capacity $\mathrm{K}^{\mathrm{C}}<\mathrm{K}^{\mathrm{M}} / 2$ will yield higher cooperative profits for the firms, but only if the smaller capacity choice helps to sustain a more collusive price in periods of low demand. This latter condition can only be true provided that $\mathrm{K}^{\mathrm{C}}<\mathrm{D}_{1}\left(\mathrm{P}_{\mathrm{L}}^{\mathrm{C}}\right)$ in equilibrium. Only then would the lower capacity choice reduce the current incentive to defect in low demand states, and thus have the potential for raising the sustainable cooperative low-demand price. However, such a reduction in cooperative capacity below $\mathrm{K}^{\mathrm{M}} / 2$ will clearly not be optinal provided that, given cooperative capacity $K^{C}-K^{M} / 2$, the sustainable low-demand price $P_{L}^{C}$ is sufficiently close to the fully collusive price $\mathrm{P}_{\mathrm{L}}^{\mathrm{M}}$. Under this condition, the cost of lower capacity in terms of foregone high-demand profit will outweigh the benefit in terms of increased profit in the low demand state. While noting that the qualitative nature of our results would be preserved for any cooperative capacity choice $\mathrm{K}^{\mathrm{C}}<\mathrm{K}^{\mathrm{M}} / 2$ provided only that perfect price collusion given $\mathrm{K}^{c}$ is not sustainable, for ease of exposition we choose to restrict our attention to the case where $P_{L}^{c}$ is "close to" $P_{L}^{M}$ 
in equilibrium. Thus, in deriving the most cooperative equilibrium for the firms we set cooperative capacity at $\mathrm{K}^{\mathrm{C}}=\mathrm{K}^{\mathrm{H}} / 2$.

We begin by characterizing the most cooperative price function taking the present discounted gains from maintaining future cooperation w as fixed. Recall that, for $k^{c}=K^{M} / 2$, the most cooperative price sustainable in high demand states is the fully collusive price

$$
\mathrm{P}_{B}^{C}(\omega)=\frac{\alpha_{B}-\mathrm{K}^{H}}{\beta}
$$

At this price, each firm sells its capacity $k^{C}=k^{M} / 2$. Thus, the only incentive a firm might have to defect would come from deviating to a higher price, which can never be profitable given cooperative capacity $k^{C}=k^{M} / 2$ since firms face positive marginal revenue (and zero marginal cost) in high demand states. Hence, defection in high demand states is not an issue.

Consider, then, a firm's current incentive to defect from the cooperative price $P_{t}^{t}$ in a period of low demand. If a firm defects, it will do so by shaving its price below $P_{L}^{c}$ and capturing the entire market (recall that $(9)$ ensures that $K^{c} \geq D_{L}\left(P_{L}^{c} \geq 0\right)$ ). Its current gains from defection are then given by

(37) $\Omega\left(P_{L}^{c}\right)=\frac{P_{L}^{c} \cdot D_{L}\left(P_{L}^{c}\right)}{2}$.

Using (37) the cooperative price in low demend states must satisfy 


$$
\frac{P_{i}^{C} D_{L}\left(P_{i}^{C}\right)}{2} \leq \omega\left(P_{i}^{C}, P_{B}^{C}\right)
$$

where $\omega(\cdot)$ is itself a function of equilibrium cooperative prices.

Assuming that the perfectly collusive outcome is not sustainable in the low demand state, the most cooperative low demand price $P_{i}^{C}$ will satisfy

(38) $\frac{P_{L}^{C} D_{L}\left(P_{L}^{C}\right)}{2}=\omega$

where $\omega$ is for now taken as a parameter. Explicit calculation yields a

$$
P_{L}^{c}(\omega)-\frac{\alpha_{1}-\sqrt{\left(\alpha_{1}\right)^{2}-8 \beta \omega}}{2 \beta} .
$$

Therefore, the most cooperative price function as a function of $\omega$ is given by

(39) $P_{i}^{f}(\omega)- \begin{cases}\frac{\alpha_{\mathrm{L}}-\sqrt{\left(\alpha_{\mathrm{L}}\right)^{2}-8 \beta \omega}}{2 \beta} & \text { if } 1-\mathrm{L} \\ \frac{\alpha_{\mathrm{H}}-\mathrm{K}^{\mathrm{H}}}{\beta} & \text { if } 1-\mathrm{H}\end{cases}$

- The high price satisfying (38) is strictly greater than $P_{\mathrm{L}}^{M}$ (see (26)). Therefore, the optinal defection price $\left(P_{i}^{M}\right)$ would lie below this price by a discrete amount, and the gains from defection would be higher than w. As such, this price can be eliminated because it is not, in fact, sustainable as a cooperative price. 
While (39) gives the most cooperative pricing function $P_{1}^{c}$ as a function of the present discounted gains from maintaining the cooperative arrangement into the infinite future $\omega, \omega$ is in fact itself a function of $P_{i}^{c}$. Thus, the next step is to solve for the fixed point $\hat{\omega}$, where " " $s$ denote most-cooperative equilibrium magnitudes. The fixed point, $\hat{\omega}$, ensures that the $P_{i}^{c}$ supported by $\hat{\omega}$ yields present discounted gains from maintaining the cooperative arrangement into the infinite future which are in fact equal to $\hat{\omega}$. To solve for $\hat{\omega}$. first note that $\omega$ is defined as (40) $\omega=\frac{\delta}{1-\delta}\left[\operatorname{En}\left(i, K^{C}, P_{1}^{C}\right)-E \Pi\left(i, K^{N}, P_{i}^{N}\right)\right]$

where $\delta \epsilon(0,1)$ is the discount factor. Explicit calculation allows (40) to be rewritten as

(41) $\omega=\frac{\delta}{1-\delta}\left\{\rho\left[P_{B}^{C}(\omega) \cdot \frac{K^{M}}{2}-P_{B}^{N} \cdot K^{N}\right]+(1-\rho)\left[P_{L}^{C}(\omega) \cdot \frac{D_{L}\left(P_{L}^{C}(\omega)\right)}{2}\right]-r\left[\frac{K^{N}}{2} \cdot K^{N}\right]\right\}$

Solving for the fixed point of (41) yields

(42) $\hat{\omega}=\left[\frac{\delta}{1-2 \delta+\delta \rho}\right]\left(\rho\left[\left(\frac{\alpha_{E}-K^{M}}{\beta}\right) \cdot \frac{K^{M}}{2}-\left(\frac{\alpha_{B}-2 K^{M}}{\beta}\right) \cdot K^{N}\right]-r\left[\frac{K^{M}}{2}-K^{N}\right]\right\}$.

Using (42), the equilibrium most cooperative price function $\hat{\mathrm{P}}_{1}^{\mathrm{c}}$ then comes from evaluating (39) at $\hat{\omega}$, provided that the resulting $\hat{\mathrm{P}}_{L}^{c}$ is "near" but not greater than $P_{L}^{M}$, i.e., provided that $\hat{\omega}$ is near but not greater than 
$\alpha_{L}^{2} / 8 \beta$ (see (26) and (39)).

Finally, glven $\hat{\mathrm{P}}_{\mathrm{L}}^{c}$ and $\hat{\mathrm{P}}_{\mathrm{b}}^{c}$, we need to determine the conditions under which firms have no incentive to defect from $\mathrm{K}^{\mathrm{C}}-\mathrm{K}^{\mathrm{H}} / 2$. Calculations similar to those leading up to (32) yleld an expression for the current Incentive to defect from cooperative capacity at $\mathrm{K}^{\mathrm{C}}=\mathrm{K}^{\mathrm{H}} / 2$, given by

(43) $\Omega\left(K^{K}\right)=\rho \frac{\left(K^{M}\right)^{2}}{16 \beta}-(1-\rho) \hat{\omega}$

Hence, the requlrement that $n\left(K^{C}\right) \leq \hat{\omega}$ at $k^{C}-K^{M} / 2$ reduces to $\left(\frac{D}{2 \cdot \rho}\right) \frac{\left(K^{M}\right)^{2}}{3} \leq$ : The assumption that the fully collusive capacity choice $K^{M} / 2$ is sustainable in equilibrium $\left(\Omega\left(K^{C}\right) \leq \hat{w}\right.$ at $\left.K^{c}-K^{M} / 2\right)$ in combination with (9) and the assumption that the fully collusive low-demand price is not sustalnable along the equilibrium path $\left(\hat{\mathrm{P}}_{\mathrm{L}}^{\mathrm{C}}<\mathrm{P}_{1}^{\mathrm{H}}\right)$ Imply three sets of Inequality restrictions that we have imposed on the model. As noted above, the restriction $\hat{\mathrm{p}}_{\mathrm{f}}^{c}<\mathrm{P}_{\mathrm{L}}^{M}$ is equivalent to $\hat{\omega}<\alpha_{\mathrm{L}}^{2} / 8 \beta$. Substituting (42) Into this inequality and sinplifying yields the relation

(44) $\frac{\alpha_{t} \cdot \beta r / p}{a_{l}}<\sqrt[3]{(1-2 \delta+\delta p) /(\delta p)}$.

Rewriting equation (9) as $\frac{a_{4} \cdot \beta r / p}{a_{i}} \geq 4$ and using (44) reveals that a range of values for the paraneters $\alpha_{i}, a_{l}, \beta$, and $r$ exist which satiafy (9) and ylold $\hat{\mathrm{P}}_{\mathrm{L}}^{c}<\mathrm{P}_{\mathrm{t}}^{\mathrm{H}}$. for any choice of $\delta$ and $\rho$ satisfying (45) $6<\frac{9}{18+7 p}$. 
Condition (45) reflects the fact that if $\delta$ were sufficiently large (so that (45) were violated), then the fully collusive low-demand price could be sustained, contrary to our assumption that $\hat{\mathrm{p}}_{\mathrm{L}}^{\mathrm{C}}<\mathrm{P}_{\mathrm{L}}^{\mathrm{M}}$.

In a similar manner, the condition that $\Omega\left(K^{\mathcal{C}}\right) \leq \hat{\omega}$ at $K^{\mathcal{C}}-K^{M} / 2$ can be reduced to

(46) $\delta \geq \frac{9}{34-17 \rho}$.

Hence, the assumption that the fully collusive capacity choice $\mathrm{K}^{\mu} / 2$ is sustalnable in equilibrium amounts to placing restrictions on $\delta$ and $\rho$ (given by (46)) which ensure that $\rho$ is not "too large." Intultively, the current incentive for a firm to defect to a higher capacity will be small provided that the likelihood of a high demand realization $(\rho)$ is low, since only in high demand states would this defection pay off. Hence, with the probability of high demand realizations not too large, the collusive difficulties of firms will be restricted to their ability to maintain high prices in low demand states.

Finally, putting (45) and (46) together ylelds the following bounds on $\delta$ as a function of $\rho$ which, 1 f satisfied, guarantee that ( 9 ) and the conditions that $n\left(K^{C}\right) \leq \hat{\omega}$ at $K^{C}-K^{M} / 2$ and that $\hat{P}_{L}^{C}<P_{L}^{M}$ will all be satisfied for a range of values of the remaining parameters $\alpha_{h}, \alpha_{1}, \beta$, and r:

(47) $\frac{9}{34-17 p} \leq \delta<\frac{9}{18+7 p}$. 
Provided that $\rho<2 / 3$, a range of $\delta$ s exist which satisfy $(47)$ and. consequently, which assure the existence of a range of values for the remaining parameters of the model consistent with the inequality restrictions we have imposed.9

\section{Dumping}

In this section we introduce antidumping law into the domestic country and explore the way in which the tacit collusive equilibriun of the previous section is affected when the domestic firm is given the opportunity to bring antidumping suits against its foreign rival. We begin with a brief description of the relevant aspects of U.S. antidumping law.

\section{Description of U.S. Antidumping Law}

Antidumping law has had a long and complex legislative history in the U.S. which we do not attempt to review here. Instead, we provide a brief summary of the steps Involved in a dumping case under current U.S. law, from initiating an antidumping duty investigation to the final determination and assessment of duties. ${ }^{10}$ We then attempt to distill the key elements of this process, with the aim of capturing these elements in our subsequent

- It should be reiterated here that we have imposed the condition that $\Omega\left(K^{c}\right) \leq \hat{\omega}$ at $K^{c}-K^{H} / 2$ only for ease of exposition. The qualitative nature of our results will hold for any sustainable cooperative capacity choice so long as (9) and the condition that $\hat{\mathrm{P}}_{\mathrm{L}}^{C}<\mathrm{P}_{\mathrm{L}}^{\mu}$ are satisfied.

10 The Trade Agreement Act of 1979 involved a major rewriting of U.S. antidumping law. The Trade and Tariff Act of 1984 contains several amendments to the antidumping law of the 1979 Act that, while substantive, are not relevant for the particular issues we consider here. 
modeling.

Once an antidumping petition is filed with the Commerce Department's International Trade Administration (ITA) and with the International Trade Commission (ITC), the ITA has 20 days to make a "petition determination," that is, to decide whether the petition is in order and, if so, to commence an investigation. ${ }^{11}$ The ITA must notify the ITC promptly of its petition determination. If affirmative, the ITC then has 45 days to make a "preliminary determination" based on the "best available information" (typically that supplied by the petitioner) of whether there is reason to believe that the industry under review is "materially injured" or "threatened with material injury" or that the establishment of the industry "is materially retarded" as a result of imports. If the ITC's preliminary determination is negative, the investigation is terminated. Provided that the ITC's preliminary determination is affirmative, and within 160 days of the Initial filing of the suit (or within 90 days if all interested parties agree to a "waiver of verification"), the ITA must make a "preliminary determination" of whether there is reasonable evidence that merchandise "is being sold, or is likely to be sold at less than fair value."12 A negative preliminary determination by the ITA does not terminate the investigation. However, if the preliminary determination of the ITA is affirmative, it must provide an estimate of the "dumping margin," and is then required to order "the "suspension of liquidation" of the affected imported goods and the

11 Petitions can be either "self-initiated" by the ITA or initiated by an "interested party" on behalf of the industry. The former is by far the exception, with the most prominient example being the Trigger Price Mechanism

12 In "extraordinary complicated" cases, the ITA may postpone making its preliminary determination until the 210 th day after filing. 
posting by importers of a cash deposit or bond to cover the estimated dumping dutles payable, pending the final ouccome of the investigation. If the industry alleges "cricical circumstances" and the ITA finds evidence of elther a history of dumping in the industry or that importers were or should have been knowledgeable about ongoing dumping, or if chere are "massive" imports of the relevant product over a "relatively short period," the dumping duties can be applied retroactively 90 days prior to the "suspension of liquidation" order.

At chis point the investigation may be terminated or suspended, or it may continue on to the final determination. Termination occurs if and only if the petition is withdrawn by the petitioner (che industry). This usually comes about as a result of price agreements reached by the domestic industry and forelgn firms named in the suit. Suspension occurs if the foreign firms that are the subject of the durping allegation reach an agreement with the ITA to eliminace sales to the U.S. market at less than fair value or to cease exporting to the U.S. market completely. ${ }^{13}$ In the case of suspension. any violation of the agreement will result in reinitiation of the investigation. If the case is neither terminaced nor suspended, the ITA must within 75 days of 1 ts preliminary determination make a "final determination" of whether the merchandise under Investigation "is being, or 1s likely to be" sold in the U.S. at less than fair value. ${ }^{14}$ If the ITA's

13 Under "extraordinary clrcumstances," an agreement by the accused forelon firms to eliminate the "Injurlous effect" of their actions may be sufficient to suspend the investigation.

14 The ITA may postpone its final determination unt11 the 135 th day after tcs preliminary determination if requested to do so by either the petitioner or the flrms agalnst which the dumplng allegations were made. 
preliminary determination was affirmative, then the ITC must make its final determination of injury within 45 days of the ITA's final determination (or within 120 days of the ITA's preliminary determination, whichever is later) If the ITA's preliminary determination was negative, and its final determination is affirmative, then the ITC has 75 days from the ITA's affirmative final determination to make its final determination of injury. Lastly, if the final determinations of both the ITA and ITC are affirmative. the ITA has 7 days within which to instruct customs officers to assess the appropriate antidumping duties. If either the ITC or the ITA determination is negative, the investigation is terminated.

As is evident from this brief review, foreign firms have ample opportunity during the course of the investigation to take actions which elther terminate or suspend the proceedings. The former requires reaching agreement over price (and quantity) with petitioners, i.e., donestic producers, while the latter requires reaching agreement with the ITA. A third option for foreign firms is simply to "behave," so that the final dumping determination is negative. In this regard, Prusa (1988) reports that over one third of the U.S. antidumping investigations initiated between 1980 and 1985 were eventually withdrawn, with over half of the remaining sults ultimately rejected by the ITC/ITA. ${ }^{15}$ on the other hand, if the investigation results in a positive dumping determination, antidumping duties can be imposed on imports potentially dating from the time of the * initial filing. Taken together, these two observations suggest that the

15 Agreements between foreign firms and domestic petitioners are encouraged under the Noerr-Pennington doctrine which exempts such parties from prosecution under U.S. antitrust law. See Prusa (1988) for a thorough analysis of this exemption and its 1mplications for the effects of antidumping law. 
filing of antidumping suits might be viewed as a mechanism by which domescic firms can alter the incentives of foreign firms to aggressively pursue domestic market share. In particular, by flling a petition at the beginning of a period in which dumping is likely to be a problem, the domestic industry can assure that dumping by foreign firms will be met by antidumping duties applied to that period's sales. 18 This characterization of antidumping law motivates the modeling approach we pursue below.

\section{Modeling antidumping law}

For the purposes of the formal model, we take dumping by the forelgn firm to be symonymous with a defection from the cooperative price, i.e., cutting its price to staal market share from the home firm. With the above discussion as our guide, we model antidumping law as providing the home $f 1 \mathrm{rm}$ with the opportunity to change the foreign firm's payoff in the event of a foreign defection from the cooperative price. Specifically, for the cost of filing the suit, the home firm is able to assure that a foreign defection from the cooperative price will be met by an antidumping duty in the period in which defection takes place. ${ }^{17}$

18 We abstract in this characterization from any "noise" in the ITA/ITC decision and assume that an antidumping duty is imposed if and only if dumping has occurred. Accordingly, we also abstract from the foreign fira's cost of defending itself during the antidumping proceedings.

17 If the punishment (antidumping duty) were delayed until the period after a defection is observed, the basic arguments of this section would still carry through though in a less transparent way. Note also that we have chosen to proceed as if the introduction of domestic antiduming law would have no Impact on the static Nash equilibrium derived earlier, and thus have assumed that the presence of domestic antiduming law has no impact on firm payoffs in the punishment phase of the dynamic game. It can be shown that antidumping suits will in fact never be filed in the static Nash equilibrium (and thus that the static Nash payoffs remain unchanged 
We now amend the dynamic model studied above and introduce antidumping law into the home country. The timing of moves in the game is as follows. As before, at the beginning of any period, firms simultaneously set capacity $K$ and $K \star$ facing per unit capacity costs $r>0$, after which the state of demand is revealed. It is at this point that the home firm now has the option of filing an antidumping suit against the foreign firm at a filing cost F>0. With the decision of whether or not to file common knowledge, the firms then. simultaneously set prices for the period.

Consider first the high demand state. Since the porential benefits for the home firm associated with filing a suit stem from relaxing the incentive constraint of the foreign firm, it is clear that a suit will never be filed in the high demand state, as long as $F>0$. This is because in the high demand state the two firms already collude perfectly (the incentive constraints don't bind), so that paying a fee $F$ to reduce the foreign $f 1 \mathrm{rm}$ 's payoff in defecting from the cooperative price would yield no offsetting benefits to the home firm in the form of larger cooperative high-demand profits. ${ }^{18}$ Thus, the domestic firm will not file a suit in high demand

when domestic antidumping law is introduced) provided that the finding of "material injury" requires an import surge greater than some fixed $\epsilon>0$. and that dumping is deemed "inactionable" (with no duty forthcoming) if this mininum injury standard is not met. With this assumption, the results of Kreps and Scheinkman (1983) are unaffected by the introduction of domestic antidumping law, so that the law would have no impact on static Nash equilibrium payoffs for the domestic (and foreign) firm.

18 One might argue that the asymmetric access to antidumping law enfoyed by the home firm would allow it to "force" upon the foreign firm an asymetric sharing of the cooperative (market) capacity $\mathbf{k}^{c}+\mathbf{k}^{\mathrm{c}}$, perhaps with $k^{C}>K^{c *}$. While asymetric sharing of capacity can not be ruled out as a cooperative equilibrium, any such sharing agreement that entailed the filing of suits by the home firm in either or both states of demand would be Pareco dominated by the same sharing rule without filing (thus avoiding the filing cost $F>0$ ). Hence, one would not expect to see the filing of 
states for $F>$, and cooperation in the high demand state is unchanged from $1 t s$ description in the dynamic game of the previous section. Consider. then, the low demand state. If a suit is not filed by the home country. nothing changes from the description of the low demand state given in the previous section. In particular; the most cooperative price sustainable with the threat of Nash reversion will be below the optimal collusive price In the low demand state (given our parameter assumptions). But with Incentive constraints binding in the low demand state absent a sult (see (38)), filing a suit may, by altering the incentives of the foreign firm to defect from the cooperative price, relax its incentive constraint at the preexisting cooperative price and be worth its cost to the domestic firm by allowing greater collusion on low demand price. However, for this to happen, the incentive for the domestic firm to defect must be appeased as the cooperative price 1 s ralsed, and the only way to accomplish this is to give the donestlc firm greater market share in low demand states. Hence, Ne now explore how the flling of a sult changes the incentives to defect from the cooperative price and the impact of these changes on cooperative price and narket shares in the low demand state.

Defining $s_{t}^{c}$ as the cooperative market share for the home firm in the low demand state and, as the ad valorem antidumping duty to be levied on

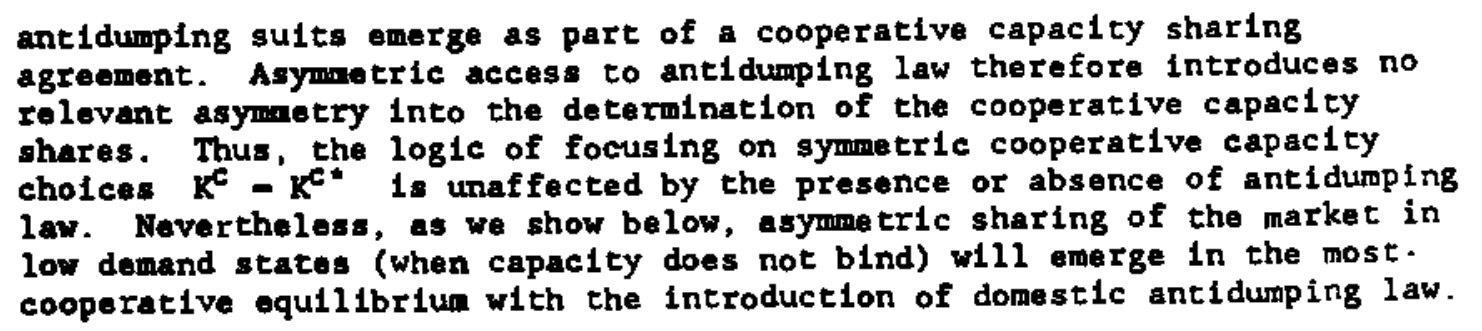


the (current) domestic sales of a foreign firm found guilty of dumping. 9 we can define the current incentive to defect in the low demand state for each firm, given that an antidumping suit has been filed by the home firm, as

(48) $\Omega\left(S_{L}^{c}, P_{L}^{C}\right)-\left(1-S_{L}^{C}\right) P_{L}^{C} D_{L}\left(P_{L}^{C}\right)$

(49) $\Omega *\left(S_{L}^{c}, P_{L}^{C}, T\right)-\left(S_{L}^{C}-T\right) P_{L}^{C} D_{L}\left(P_{L}^{C}\right)$

Becsuse of the asymmetry introduced by the existence of antidumping law in the domestic country, we now need to characterize separately the incentive constraints for both the domestic and the foreign firms. The no defection conditions which the cooperative low-demand price and market sharing rule must satisfy then become

$$
\Omega\left(S_{L}^{c}, P_{L}^{c}\right) \leq \omega
$$

and

$$
\sigma *\left(S_{L}^{C}, P_{L}^{C}, \tau\right) \leq \omega *
$$

19 For simplicity we take the magnitude of the antiduming duty, if levied, to be fixed and not necessarily reflective of the "true" dumping margin which would in this case be measured as the difference between $P_{L}^{C}$ and "constructed value" measure. Note also that while U.S. antiduming law provides for the imposition of antidumping duties on domestic importers rather than foreign exporters, it permits importers to be reimbursed by foreign exporters for the payment of dumping duties on all imports for which the agreement to purchase was uade prior to the suspension of liquidation order and where the merchandise is exported before a determination of sales at less than fair value (see Dale, 1980, pp. 104-105, note 42). Hence, ss embodied in (49), we take the incidence of the antidumping duty to fall on the foreign exporter rather than the importer of foreign products. 
Suppose that perfect collusion is not possible in low demand states even given the antidumping duty, Then the most cooperative low demand price and market shares satisfy

(50) $\Omega\left(S_{\downarrow}^{C}, P_{\downarrow}^{C}\right)=\omega$

and

(51) $8 *\left(S_{\mathfrak{l}}^{C}, P_{\mathfrak{l}}^{C}, r\right)=\omega^{*}$.

Direct calculations using (48), (49), (50) and (51) yield

(52) $S_{L}^{c}(\omega, \omega *, \tau)-\frac{7 \omega+\omega *}{\omega+\omega *}$

and

(53) $P_{\mathrm{L}}^{\mathrm{C}}(\omega, \omega *, \tau)=\frac{\alpha_{\mathrm{L}}-\sqrt{\left(\alpha_{\mathrm{L}}\right)^{2}-4 \beta(\omega+\omega \star) /(1-\tau)}}{2 \beta}$,

with $\omega$ and $\omega *$ given by

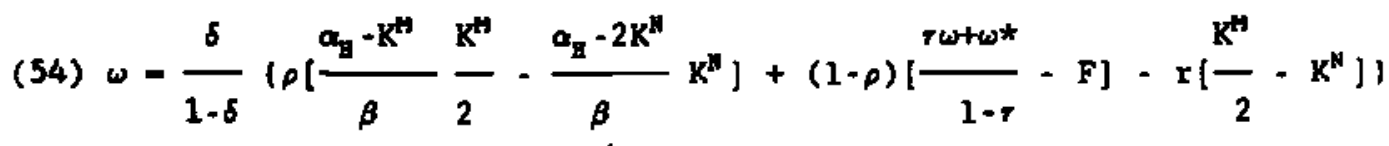


(55) $w *-\frac{\delta}{1-\delta}\left(\rho\left[\frac{\alpha_{\mathrm{B}}-\mathrm{K}^{\mathrm{M}}}{\beta} \frac{k^{\mathrm{M}}}{2}-\frac{\alpha_{\mathrm{B}}-2 \mathrm{~K}^{\mathrm{N}}}{\beta} \mathrm{k}^{\mathrm{N}}\right]+(1-\rho) w-x\left[\frac{\mathrm{K}^{\mathrm{M}}}{2}-\mathrm{K}^{\mathrm{N}}\right]\right)$.

Solving for the fixed point $\left(\hat{\omega}_{1}, \hat{\omega}_{1}^{*}\right)$ of (54) and (55) then yields

(56) $\hat{\omega}_{1}-\left[\frac{\delta[(1-\rho \delta)-(1-\delta) \tau]}{(1-\rho \delta)[1-2 \delta+\delta \rho-(1-\delta)+]}\right) 1 \rho\left[\left(\frac{\alpha_{H}-K^{M}}{\beta}\right) \cdot \frac{K^{M}}{2}-\left(\frac{\alpha_{H}-2 K^{N}}{\beta}\right) \cdot K^{M}\right] \cdot r\left(\frac{K^{M}}{2} \cdot K^{*}\right.$

$$
-\left[\frac{\delta(1-\delta)(1-\gamma)(1-\rho)}{(1-\rho \delta)[1-\delta(2-\rho) \cdot(1-\delta) \tau]}\right] F
$$

and

(57) $\hat{\omega}_{1}^{*}-\frac{\delta}{1-\delta}\left(\rho\left[\left(\frac{\alpha_{B}-K^{M}}{\rho}\right) \cdot \frac{X^{M}}{2}-\left(\frac{\alpha_{B}-2 K^{N}}{\rho}\right) \cdot K^{N}\right]+(1-\rho) \hat{\omega}_{1} \cdot r\left(\frac{X^{M}}{2}-K^{N}\right]\right\}$.

To analyze the way in which the introduction of antidumping law in the domestic country effects the tacit collusive equilibrium in the absence of such law, we note first that the home firm can always choose not to file anc receive equilibrium expected discounted gains from tacit collusion equal to w. Thus, the domestic firm will choose to file antidumping suits in low demand states if and only if

(58) $\hat{\omega}_{1}>\hat{\omega}$,

that is, if (and only if) the domestic firm's equilibrium expected 
discounted gains from tacit collusion (net of filing costs) are greater by f111ng in low demand states than by not filing at all. Using (42) and (56), 1e $1 \mathrm{~s}$ stralgheforward to check that

(59) $\hat{\omega}_{1}(F-0, \tau-0)=\hat{\omega}$.

Moreover, using (56), direct calculation establishes that

(60) $\frac{d \hat{\omega}_{1}(F-0, \tau-0)}{d \tau}>0$.

Since the domestic firm w11l choose to flle antidumping suits in low demand

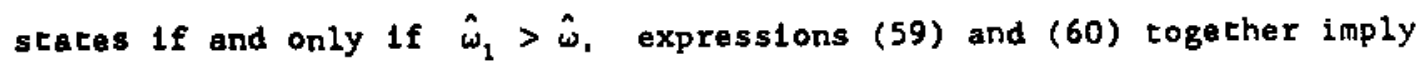
that for small flilng costs $F$ there exists a range of antidumping duties T such that the domestic firm files antldumping suits if and only if the dewand realization for the perlod 1s low. Note that the domestlc firm files antidumping sults in the presence of low demand, even though no antidumping dutles w11l ever actually be levied in equilibrium. The entire effect of fling comes in the form of a threat to punish the forelgn firm if it should "nlsbehave" which, because it 1s credible, never has to be 1mplemented. 20 Next consider the effect of domestlc antiduming law on the forelgn f1rm. Uaing (42), (56), and (57), 1t can be shown that

20 If the petitioner is taken to suffer a loss of "good standing" with the ITC whenever 1t falls (after the inltial sales-at-less-than-fair-value determination) co withdraw a sult which is ultioately rejected in the final determination, and if prices are set for the perlod by the time of the intelal sales-at-less-than-falr-value determination, then equilibrium will have al1 sults and in withdrawal. 
(61) $\hat{\omega}_{1}^{*}>\hat{\omega}$ if and only if $\hat{\omega}_{1}>\hat{\omega}$

and

(62) $\hat{\omega}_{1}>\hat{\omega}_{1}^{*}$ if and only if $\hat{\omega}_{1}>\hat{\omega}$.

Putting (61) and (62) together yields

(63) $\hat{\omega}_{1}>\hat{\omega}_{1}^{*}>\hat{\omega}$ if and only if $\hat{\omega}_{1}>\hat{\omega}$.

In words, if (and only if) the underlying parameters of the model are such that antidumping law is utilized by the domestic firm (i.e., if (58) holds so that filing occurs in low demand states), then both domestic and foreign firms gain from the existence of domestic antidumping 1 aw, with the home firm gaining more (net of filing costs) than the foreign firm.

Finally, we consider the mechanism through which the home firm gains more than the foreign firm from the existence of domestic antidumping laws. despite the fact that it is the home firm that must incur the filing costs This mechanism is the shifting of cooperative market share to the domestic firm in low demand states. To show that the domestic firm gains market share in low demand states as a result of filing the suit, we note that. using (54) and (55), and substituting in (48) through (51), expression (62) implies that the equilibrium most cooperative market share for the domestic firm in low demand states, $\hat{S}_{1}^{c}(\tau)$, satisfies 
(64) $\hat{\mathrm{S}}_{\mathrm{L}}^{\mathrm{c}}(r)>\frac{1}{2}$

provided only that $\hat{\omega}_{1}>\hat{\omega}$ (so that filing occurs in low demand states). Since cooperative market shares are symmetric in high demand states and symetric in low demand states in the absence of antidumping law, (64) implies that the filing of an antidumping suit by the domestic firm in low demand states is accompanied by an increase in the cooperative market share of the domestic firm. Such a shift in market share in the presence of antidumping suits is required in order to mitigate the incentive of the domestic firm to defect from price cooperation as the cooperative price is moved to the more collusive level facilitated by the suit. Hence, by facilitating both higher collusive (low-demand) prices and greater domestic (low-demand) market share, antidumping law contains both rent-augmenting and rent-shifting elements.

Finally, while wo have stressed the positive implications of our analysis, it is important to note here that the rent-shifting aspect of antidumping law is not sufficient to make it attractive as a policy for raising the sum of the expected present discounted value of domestic producer and consumer surplus in the industry. ${ }^{21}$ To see that this is true, note first that the introduction of domestic antidunping law leaves collusive capacity and collusive high-demand price unaffected, so that only the surplus in low-demand states need be considered. But the introduction

21 We ignore here the filing costs born by the domestic firm as well as any resource costs associated with the ITA/ITC procedures. Such costs vould only strengthen the conclusion. 
of antiduming law facilitates greater price collusion in low demand states. so that total market surplus (the sum of domestic consumer surplus, domestic producer surplus, and foreign producer surplus) must decline. Hence. a sufficlent condition for the sum of domestic consumer and producer surplus In low demand states to fall with the introduction of domestic antidumping law is that foreign producer surplus not decline. This condition is guaranteed by (63). Thus, in spite of the domestic rent-shifting effects of the policy, the sum of expected discounted producer and consumer surplus at home must decline with the introduction of domestic antidumping law.

\section{Conclusion}

We have attempted in this paper to model the impact of domestic antidumping law on the behavior of domestic and foreign firms that are tacitly colluding in the domestic market. Our major conclusions can be summarized as follows. The filing of an antidumping suit can become a useful mechanism with which to enforce price collusion during perlods when collusion is otherwise difficult to sustain. In particular, if firms face stochsstic market demand and must install capacity before the resolution of this uncertainty, price collusion will be most difficult to sustain in periods of low demend, and it is in such periods that antidumping suits will tend to arise. By reducing the incentives of the foreign firm to defect from any collusive price, the filing of an antidumping suit by the domestic firm allows a greater degree of collusion (a higher price) to be sustained in low demand states, but only by shifting cooperative market share toward the domestic firm to appease its incentive to defect. As a consequence, the introduction of antiduming law into the domestic country will result in the 
filing of suits in low-demand states, and to higher low-demand prices, greater market share for the domestic firm in low-demand states, and greater expected discounted profits for foreign and domestic firms alike, all without the imposition of a single antidumping duty, However, once domestic consumer surplus is also considered, the domestic country must lose from the introduction of antidumping law.

While these results are strong and intuitive, they have come from a model which is highly scylized and special in a number of ways. We have simplified the analysis greatly by limiting the parameter space and restricting our attention to 1.1.d. shocks to market demand. Future theoretical work must focus on the degree to which the strong insights which emerge from this model are preserved in more general settings.

Nevertheless, we feel that the positive predictions of even this simple model are sufficiently rich to allow meaningful empirical exploration of the relevance of our ideas for the workings of U.S. antiduming law in practice. This is especially true given the sharp predictions which emerge from a comparison of our resules here with those in Staiger and Wolak (1989) concerning the impact of market structure in the petitioning industry on the frequency with which antidumping peticions should end in the imposition of duties. While both models predict the filing of antiduming suits in lowdesand states, In Staiger and Wolak (1988) wo assume that the petitioning industry is perfectly competitive and find that antidumping suits against collusive foreign firms always end in ducles, while our results here imply that when the potitioner is a member of the cacitly collusive (international) cartel the filing of antiduming suits serves a fundamentally different purpose and antiduming duties are never actually 
imposed. Taken rogether, these stylized findings suggest that the frequenc: with which antidumping petitions end in the imposition of duties should be higher for more competitive peritioning industries. We hope to test the empirical implications of these and other results in future work. 